\title{
Impact of climate change and anthropogenic pressure on the water resources of India: challenges in management
}

\author{
K. Shadananan Nair \\ Nansen Environmental Research Centre (India), Kochi-682016, Kerala, India \\ Correspondence to: K. Shadananan Nair (nair59@yahoo.com) \\ Published: 17 October 2016
}

\begin{abstract}
Freshwater resources of India are getting fast degraded and depleted from the changing climate and pressure of fast rising population. Changing intensity and seasonality of rainfall affect quantity and quality of water. Most of the rivers are polluted far above safety limits from the untreated domestic, industrial and agricultural effluents. Changes in the intensity, frequency and tracks of storms salinate coastal aquifers. Aquifers are also under the threat from rising sea level. Groundwater in urban limits and industrial zones are far beyond safety limits. Large-scale destruction of wetlands for industries and residential complexes has affected the quality of surface and groundwater resources in most parts of India. Measures to maintain food security and the new developments schemes such as river linking will further deteriorate the water resources. Falling water availability leads to serious health issues and various socio-economic issues. India needs urgent and appropriate adaptation strategies in the water sector.
\end{abstract}

\section{Introduction}

Demand in water has been escalating in India with fast rising population. Population has already crossed 1.2 Billion and it is expected to stabilize only by the year 2050 at $1.5 \mathrm{Bil}-$ lion. Increasing domestic, agricultural, and industrial water requirements are serious challenges for India as the economy is still not very strong to implement large development projects and to find adaptive mechanisms for changing climate conditions. Indian economy and life of more than half of the population have been traditionally linked to agriculture or agriculture-related industries. Monsoons, the source of water for India undergoes wide inert-annual variation associated with global anomalies. Wide disparity in rainfall is reflected in local climate and water resources. As a result, vast areas of interior India are arid and semi-arid. Most of these regions are rich in agriculture where another agricultural revolution is possible, if some more water is available for irrigation. Any extremes in climate leading to further water shortage in such regions will disrupt all measures to attain food security. Available resources are getting fast deteriorated and depleted. Groundwater level in the country is receding fast, as a result of changing rainfall seasonality, land use changes and overexploitation. Proper assessment and care- ful management of water resources are utmost important. India is going to face a very serious water scarcity in two or three decades, unless new resources are identified and effective conservation and management measures are not resorted to in its major river basins (Fig. 1). Two-third of India's available freshwater is lost due to evaporation and runoff into the Sea, while there exists a freshwater crisis in many parts at different times of a year (UN Newsletter, 1999). Study of the World Watch Institute predicts that the Ganges and other rivers vital for farming in heavily populated India will run dry for a part or all of the dry season, 30 years from now (Science update, 1997).

Renewable water resources of India are about $4 \%$ of the global availability (IWRS, 1998). Today, around $83 \%$ of the population comes under the drinking water supply schemes. Only $35 \%$ of the cultivable land is irrigated, while $70 \%$ of the runoff wastefully joins the Sea. Water deliveries in India rarely correspond in quantity and timing of the true requirements (Postel, 1989). The annual precipitation of nearly $4000 \mathrm{Bm}^{3}$ contributes to the formation of twelve major river basins and eight other basins formed by the combinations of medium and minor basins. The major and medium river basins contribute over $90 \%$ of the total runoff in the country. 
The Indo-Gangetic planes have enormous amount of water, but the current method of utilization is not appropriate (Serageldin, 1998). Of the total water potential of $1869 \mathrm{Bm}^{3}$, only $1122 \mathrm{Bm}^{3}$ can be put to beneficial use. Out of this, $690 \mathrm{Bm}^{3}$ is surface water and $432 \mathrm{Bm}^{3}$ is replenishable groundwater (Ministry of Water Resources, 1998). There will be a considerable gap between the water need and availability in various basins in two or three decades from now. An in-depth study based on water balance and of the expected changes in water resources become necessary to formulate measures to meet the challenges in future.

\section{Analysis and results}

Characteristics of rainfall over India have been analysed using the data provided by the India Meteorological Department. Changes in the seasonality of rainfall have been studied using the method suggested by Walsh and Lawler (1981). Changes in per capita water availability in the major river basins during the period 2010-2030 have been estimated, considering the decadal population growth and changes in rainfall and temperature patterns adopted by Government of India (MoEF, 2010), For this, changes in hydrological parameters have been computed using the water balance method developed by Thornthwaite (1948) and modified by Thornthwaite and Mather (1955) that has been modified to suit the local conditions.

\section{Rainfall and water availability}

In general, monsoons and the local weather systems produce a mean annual rainfall of around $108 \mathrm{~cm}$ over India. Effect of orography results in up to $400 \mathrm{~cm}$ rainfall in the extreme northeast region and in the southwest coast. Isolated regions in the northeast get more than $1000 \mathrm{~cm}$ and in the west coast, up to $700 \mathrm{~cm}$. Rainfall is less than $20 \mathrm{~cm}$ in the north-western drylands. The southwest monsoon (JuneSeptember) is the principal rainy season for the country. During the north-east monsoon period (October-December), the chief areas of rainfall is confined to the southern tip of the peninsula, the east coast and isolated areas in the north-east and the extreme north. Major part of interior India is semi arid, but rich agricultural lands and if some more water becomes available here by efficient water management, it may help a lot in solving future food crisis.

It is the temporal distribution of the rainfall, more than the total amount that affects the water availability of a region. A less seasonal (more distribution through months) rainfall permits more soil moisture retention and increases water availability in dry months. Though the rainfall is heavy in the west coast hill regions, most of it is highly seasonal and confined to two or three months. Water from the heavy rainfall flow fast wastefully into the ocean through the steep hill slopes, before it could be harnessed. In general, rainfall is less seasonal in the southern tip of Peninsular India, as this region gets rainfall from both monsoons and local systems. Similarly, it is less in the northern parts also, due to the winter rainfall associated with the passage of Western Disturbances. Effect of the northeast monsoon and depressions and cyclones in winter produce a less seasonal pattern in the east coast. Rainfall is becoming more and more seasonal in almost all parts of India. The seasonality of rainfall is always reflected in water resources.

The per capita water availability (from surface water surplus, after meeting requirements for evapotranspiration and soil moisture recharge) in the basins ranges from $17730 \mathrm{~m}^{3}$ in the Brahmaputra to $269 \mathrm{~m}^{3}$ in Sabarmati (Table 1). Even today, availability on annual basis is less than requirement in many of the basins, especially in the interior peninsula. When the entire basin is considered, it is satisfactory only for the Brahmaputra. The study reveals that by the year 2030 , at the current rate of growth of population and with the predicted increase in global temperature, the availability will be drastically reduced in all the cases. However, situation will be hopeful in the northeast Brahmaputra region. In almost all parts of India, seasonal water deficiencies show an increasing trend and the surpluses show a decreasing trend. According to WMO, rainfall increase may be considerable in the north-west India, but, it may be very low in the south and north, where the increase in precipitation may not be able to compensate for the reduction in soil moisture due to rise in temperature (Bhalme, 1997). Northeast India has high values of per capita availability. But, the very high growth rate of population in these regions will reduce the availability up to one-fifth of the present level by 2030. Seasonality of rainfall is reflected in the water surpluses. If the rainfall is highly seasonal, there can be a seasonal surplus though the amount is small (needs for evapotranspiration and soil moisture recharge are temporarily met here). Therefore, change in seasonality may lead to more seasonal water crisis. In India, population increase is a more serious issue compared to the effect of global warming on water resources.

\section{Management issues}

The study points out that there will be a considerable shortage of water in all river basins of India by the year 2030 . Government is planning to meet the estimated freshwater requirements from exploitable surface and ground water resources. In fact, any further need will have to be met with new resources to be explored or better management. Study of the World Watch Institute predicts that the Ganges and other rivers vital for farming in heavily populated India will run dry for a part or all of the dry season, 30 years from now (Science update, 1997). Increased urbanization in India has stressed water use and water supply infrastructure beyond capacity. One-third of the urban population and one-twelfth of the total population live in 23 metropolitan cities and most of them are near major rivers. Growth of mega cities adds 
Table 1. Water availability in the major river basins.

\begin{tabular}{lrr}
\hline River basins & $\begin{array}{r}\text { Per capita water } \\
\text { availability }\left(\mathrm{m}^{3}\right) \\
(\text { Year } 2010)\end{array}$ & $\begin{array}{r}\text { Per capita } \\
\text { by year } \\
2030\left(\mathrm{~m}^{3}\right)\end{array}$ \\
\hline Indus & 1250 & 534 \\
Ganaga & 1150 & 490 \\
Brahmaputra & 17730 & 6252 \\
Narmada & 1148 & 434 \\
Tapi & 721 & 504 \\
Brahmani \& Baitarni & 2112 & 1147 \\
Mahanadi & 2107 & 1243 \\
Godavari & 1695 & 670 \\
Krishna & 1014 & 393 \\
Pennar & 514 & 255 \\
Cauvery & 605 & 320 \\
Sabarmati & 269 & 107 \\
\hline
\end{tabular}

more stress on water. Mega-cities have to cope with intense competition from agriculture and industry to provide their expanding populations, especially the urban poor, with adequate water supply. Mega-cities also have to address the increasing pollution of their freshwater sources from growing volumes of urban waste and the increasing environmental risks from over-abstraction of groundwater resources, inadequate drainage and floods. If the present rate of migration to cities continues, not in far future, water planning in cities will become complicated with no easy solutions. Water consumption by the thousands travelling daily to the cities for job is not considered in the urban water planning.

Only a portion of the water surplus in the basins is available for human use due to deterioration of water resources, especially during dry months when need is more. Increased demands in agricultural, industrial and domestic sectors lead to considerable imbalances in the quantity and quality of water resources. Extremes and variability in climate are likely to worsen the existing situation by further limiting the water availability. Potential changes in temperature and precipitation pattern may adversely affect soil moisture condition, annual runoff, and ground water recharge. Despite extensive efforts to improve the use and management of water resources, water demands continue to rise, contamination degrades water quality, and natural hazards, such as floods and droughts, disrupt human activities and cause extensive human suffering and economic losses. Population growth and urbanization are among the key factors underlying the enormous growth in the demand of water and the increase of environmental degradation.

Changing climate pattern is of serious concern for India. IPCC (1998) predicts an increased recession of Himalayan glaciers and increasing danger from glacial lake outburst floods in an increased temperatures and increased seasonal variability in precipitation. Reduction in average flow of snow-fed rivers and an increase in peak flows and sediment $77^{\circ} \mathrm{E}$

$88^{\circ} \mathrm{E}$

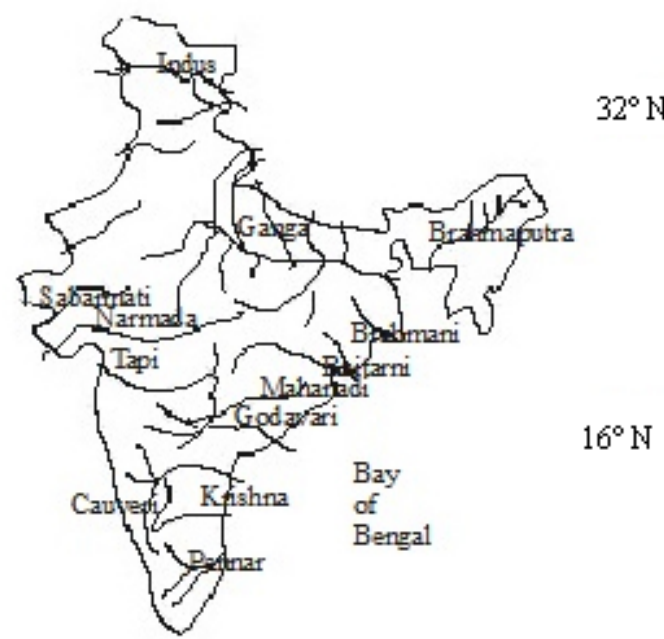

Figure 1. India - Major river systems.

yield would have major impacts on hydropower generation, urban water supply, and agriculture. Almost all parts of India are vulnerable to floods or droughts. In an altered global climate, change in such extremes can be catastrophic. Any change in the strength or seasonality of monsoons would lead to soil moisture deficiency or floods in the basins and affect water availability and runoff rates. There can be tremendous increase in the transport of sediment load of the Ganges and Brahamaputra, which already carry an extraordinarily heavy sediment load and have a high, though irregular, rate of downstream deposition. The Ganges-Brahmaputra delta is one of the world's most densely populated areas, and the effects of climate change could cause serious drainage and sedimentation problems, in addition to bank erosion and land loss. These impacts clearly would have immense socioeconomic costs.

Extreme water conditions and quality issues are major problems in water resources management. The magnitude and severity of these problems varies from one basin to another. Increasing demand is characterized by increasing competition for available water. The social, environmental and political issues related to the rivers are worsening. There exists dispute over water sharing, either national or international in almost all the basins. In India, domestic water disputes are more severe and difficult to resolve compared to international, because of various political and social reasons. Water-related environmental problems are becoming transboundary in scope as local pollution problems spread across borders due to the pressure of population growth, increased fertilizer and pesticide use, more industries and inadequate pollution controls. When the availability decreases, existing disputes may worsen or new one may start in any basins. Even the updated national water policy (MWR, 2012) of In- 
dia doesn't provide any clear suggestion for conflict resolution.

Water related health issues and economic issues are also worsening. Water-borne and vector-borne diseases spread into new areas. In two or three decades, one-third of the country will be prone to malaria. Large investments will be required to provide safe water to the growing population and for the measures for adaptation and impact mitigation. Price of reliable water is escalating. It becomes unaffordable to millions of poor people, especially in urban limits.

Shortage of surface water will increase dependency on groundwater. More water withdrawal for agriculture may lead to increased desertification, land degradation and loss of soil fertility. Substantial reduction in the area under agriculture and extensive damage to structures will not only affect the economy but also will create problems associated with shift in population to reliable basin areas. Even now, overextraction of groundwater in some basin areas has resulted in reduction of summer runoff in rivers and lowering of water level in nearby open water bodies.

Increased population and increasing demand in the agricultural, industrial, and hydropower sectors will put additional stress on water resources. Agriculture is the predominant water user in India and the gap between the need in the sector and availability will be widening, unless viable alternatives are not found. In addition to these, limited water management capacity, fragmented organizational structures, and inadequate water planning, management, and conservation are among the contributing factors to water crisis. Situation seriously underlines the need for taking up integrated plans for water conservation and utilization at basin level to meet the increasing demands of irrigation, water harvesting, human and livestock consumption, expanding industry, hydro-electric power generation, recreation, navigation and other uses.

What India needs is an appropriate and frequently updated water policy and a strong political will to implement it. Policy development should involve climate change impact on socio-economic conditions in different zones. Water management should be brought under a central control instead of the various departments making delays in decisions. Legal and institutional mechanisms are to be improved to cope with the need of the time. Even constitutional amendments become necessary to solve water problems in large basins. At present, water is a state matter and the central government has only limited role in its control. Therefore, disputes over water among states continue to be a major hazard in water related development activities.

It is true that lack of government funds have haltered progress of many projects in India. An option is private sector participation. But, private sector financing should be seen to be complementary and in no way a substitute for the state's responsibility in providing basic necessities for all. Private sector involvement is a failure in India's basic requirements sector. Any development scheme cannot suc- ceed without giving due care to the millions living well below poverty line. Water should continue to be provided free to the extreme poor and the marginal farmers. Also, social situation in India may not permit pricing easily. Awareness in conservation and management is more important.

The fundamental right of access to safe water and sanitation with environmental protection is to be ensured. But, strict control is to be made to avoid overuse and wasteful use. Satisfactory water allocation with consensus among different users is a key factor in the development of society and in maintaining harmony. Involvement of non-governmental organizations and charitable organizations are better performed in India than govt in providing basic necessities like water. People's participation should be an integral part of all aspects of water resources management.

Water has to be used in an environmentally sustainable manner in order to maximize its economic and social benefits. It should not be used faster than it is replenished, nor should it be polluted. Addressing water problems requires an inter-sectoral approach that recognizes the interlinkages - for example between land and water, agriculture and water, technology and water, health and water - that affect water management. No single mechanism or approach will be enough. However, reformation in agricultural sector is urgently needed in maximum and efficient use of water and in minimising input of pollutants. Policy packages using a mutually reinforcing mix of institutional and policy reform, and legal, economic and management instruments will be needed. Strong political decision by the state to implement the rules and regulations is most important. Traditional methods of water collection and conservation, which are environment-friendly and less expensive may be promoted. Modernisation of hydroelectric systems is necessary to get more power and to reserve more water. Water conservation should be started at the domestic level. In heavy rainfall regions, roof top water collection alone can meet the water requirements for cooking and drinking. Proper enforcement of the environmental protection laws can effectively control the degradation of water resources.

\section{Conclusions}

Rainfall over India is becoming more seasonal and this is reflected in groundwater recharge and summer water availability. Per capita availability of freshwater in all major river basins is fast decreasing, as a result of changes in climate and rise in population. Most of the basins will experience water stress by the year 2030. Available resources are getting fast depleted and degraded. Falling water availability leads to several socio-economic issues such as disputes over sharing, migration, pricing of water. National policies do not address the issues seriously. Measures for adaptation often fail because of various social, economic and political reasons. There are possibilities to overcome the growing water crisis 
through better conservation and management. For this India need a better policies and better institutional mechanism to implement the policy guidelines.

\section{Data availability}

Data of rainfall and temperature available from the India Meteorological Department (IMD) on payment, Website of IMD: http://www.imd.gov.in/pages/services_climate.php Data of population available from the Census Department, Government of India: http://www.censusindia.gov. in/2011census/population_enumeration.html Information on climate projections available from the Ministry of Environment, Forest and Climate Change, Government of India, Website: http://www.moef.nic.in/downloads/ public-information/fin-rpt-incca.pdf.

\section{References}

Bhalme, H.: Agriculture, food and climate, WCASP, 42, 5-12, 1997.

Government of India: Population Enumeration Data (Final Population), available at: http://www.censusindia.gov.in/2011census/ population_enumeration.html, last access: May 2016.

India Meteorological Department (IMD): Climatological Services, available at: http://www.imd.gov.in/pages/services_climate.php, last access: September 2015.

IPCC: The regional impacts of climate change: an assessment of vulnerability, Cambridge University Press, 1998.

IWRS: Five Decades of Water resources Development in India, IWRA Report, New Delhi, 1998.
Lonergan, S.: Climate warming and India, in: Measuring the Impact of Climate Change on Indian Agriculture, edited by: Dinar, A., World Bank Technical Paper No. 402, 1998.

Ministry of Water Resources: Water Resources Development in India 1947-1997, Govt. of India Publication, New Delhi, 1998.

Ministry of Environment \& Forests: Climate Change and India: A $4 \times 4$ Assessment, available at: http://www.moef.nic. in/downloads/public-information/fin-rpt-incca.pdf, last access: September 2015.

MoEF (Ministry of Environment and Forests): Climate Change and India: A 4X4 Assessment - A sectoral and regional analysis for 2030s, Indian Network for Climate Change Assessment, Government of India, 2010.

MWR (Ministry of Water Resources): Revised Draft National Water Policy, p. 11, Govt. of India, 2012.

Postel, S.: Water for Agriculture Facing the Limits, World Watch Paper 93, The World Resources Institute, USA, 1989.

Science Update: Water Scarcity seen in future, Publication of the US Consulate, 3-4, 1997.

Serageldin, I.: Water in the 21st Century: A Dialogue, Water Policy, 1, 29-137, 1998.

Thornthwaite, C. J.: An Approach Towards the Rational Classification of Climate, Geogr. Rev., 38, 1948.

Thornthwaite, C. J. and Mather, J. R.: The Water Balance, Publ.inClimat. Lab. Of Climat., 8, 1955.

UN Newsletter: UN and Water, 54, 3-8, 1999.

Walsh, R. P. D. and Lawler, D. M.: Rainfall Seasonality: Description, Spatial Patterns and Change Through Time, Weather, 36, 201-208, 1981. 